How to cite: Kaya, Y.Z., Üneş, F., Demirci, M., Varçin, H. (2021) Investigation of Precipitation Trend in Regional Scale Based on the Statistical Approach. 2021 "Air and Water-Components of the Environment" Conference Proceedings, Cluj-Napoca, Romania, p. 189-200, DOI: 10.24193/AWC2021_18.

\title{
INVESTIGATION OF PRECIPITATION TREND IN REGIONAL SCALE BASED ON THE STATISTICAL APPROACH
}

\author{
Yunus Ziya KAYA ${ }^{1}$, Fatih ÜNEŞ⿻ ${ }^{2}$, Mustafa DEMIRCI ${ }^{2}$, Hakan VARÇİN $^{2}$ \\ DOI: $10.24193 / A W C 2021 \_18$
}

\begin{abstract}
In recent years, hydrological trend analysis had become very popular due to global warming and climate change issues. Knowledge of the trend changes of hydrological series helps designers, engineers, and plan makers about future projections of all water related problems such as irrigation systems, water distribution systems, etc. Statistical approaches are historically very crucial for determining the trend. In this study, authors focused on determining total precipitation trend change monthly, seasonally, and annually on a regional scale. Non-parametric Mann Kendall test, Spearman's Rho test, and Sen's Slope test are used for the determination of the precipitation trend. Additionally, the total annual precipitation trend is investigated with the linear regression trend analysis method. Detailed results of each method are shared separately.
\end{abstract}

Keywords: Precipitation, Trend, Mann Kendall test, Sen's slope test, Spearman's Rho test

\section{INTRODUCTION}

Global warming, climate change issues make hydrological and meteorological problems more important day by day. Climate change effects make difference in different areas on a regional scale. Therefore, it is essential to estimate the changing trends of hydrological parameters in a specific area for handling unexpected future changes. One of the most important parameters in the hydrologic cycle is precipitation from the point of water management view. It is critical to know the changing trends of precipitation for making future water management plans such as water distribution systems, irrigation systems and even developing flood protection strategies, etc. However, the determination of a trend, calculation, or estimation of a hydrological problem is generally very complicated because of the direct and indirect effects on the hydrological process. This is why, recently data mining techniques, artificial intelligence, soft computing approaches are developed and used for the estimation of different hydrological processes because of the abilities of the mentioned models. (Demirci \& Kaya, 2019; Demirci et al., 2018; Mamak et al., 2017; Üneş et al., 2018a; Üneş et al., 2019; Üneş et al., 2018b; Kisi, 2008, 2015; Shiri et al., 2012; Zhao et al., 2013, Üneş et al.,2017). Specifically, trend analyses are used recently for streamflow, precipitation, evaporation cases. Bacanl1 \&

\footnotetext{
${ }^{1}$ Osmaniye Korkut Ata University, Civil Engineering Department, yzkoku@outlook.com

${ }^{2}$ Iskenderun Technical University, Civil Engineering Department, fatih.unes@iste.edu.tr, mustafa.demirci@iste.edu.tr, hakan.varcin@iste.edu.tr
} 
Tanrikulu, (2017) used Mann Kendall and Sen's Test to evaluate the evaporation trend in the Aegean region, Turkey. Ercan \& Yüce, (2018) searched for the trend of precipitation and temperature using weather station-based records between 19752016. Mahmood et al., (2019) investigated the climate variability and trend change of Chad basin, Africa. Serencam, (2019), used an innovative trend analysis method to make a trend analysis on total rainfall and temperature variability as a case study of the Yeşilırmak region. Tosunoğlu, (2017) evaluated the daily maximum rainfall Series in Çoruh Basin, trend variability using Mann Kendall test, Modified Mann Kendall test, Sequential Mann Kendall test, and Theil-Sen test. Fukushima et al., (2019) investigated the regionality of long-term trends and interannual variation of seasonal precipitation over India during two different periods. Kahya \& Kalayc1 (2004) used 31 year period streamflow data belonging to 26 basins over Tukey to determine the trend of streamflow. They used the Mann Kendall test, Spearman Rho test, Sen's t-test, Seasonal Kendall approaches for trend investigation. Partal \& Kahya (2005) aim to investigate the long-term annual mean and monthly total precipitation by using the Mann Kendall test and Sen's T-test. Fathian, F., et al, (2015) Mann Kendall, Spearman Rho, Sen's T methods for investigation of the trends in the annual and seasonal time series of temperature, precipitation, and streamflow over the Urmia Lake basin, Iran.

In this study, precipitation-based trend change analyses are generated using the most popular trend analyzing methods namely Mann Kendall, Spearman's Rho tests, Linear Regression trend test, and the magnitude of the trend is investigated by Sen's Slope method.

\subsection{Study area}

A weather station daily precipitation record belonging to United States Geological Survey (USGS) is used for the trend investigation. Daily records of precipitation are for 16 years between 2002-2017. The station is located in Middlesex County, USA and the given hydrologic unit of the station by USGS is 01090001 . The drainage area of the station is $17.77 \mathrm{~km}^{2}$. The location of the station is marked as it is in Fig.1.

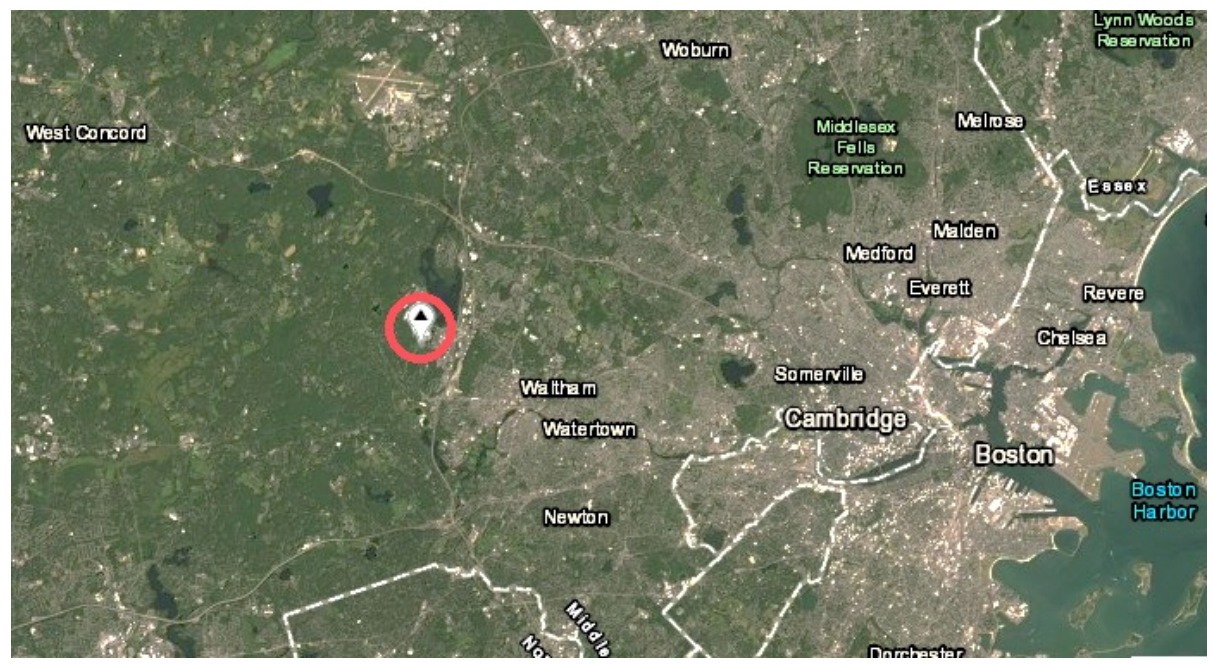

Fig. 1. Location of the weather station 
Monthly Seasonally and Annual Maximum total precipitation ( $\mathrm{mm}$ ), minimum total precipitation $(\mathrm{mm})$, Mean total precipitation $(\mathrm{mm})$, standard deviation $(\mathrm{Sx})$, and Skewness (Csx) statistics are calculated and given with Table 1.

Table 1. Used data set statistics

\begin{tabular}{c|ccccc}
$\begin{array}{c}\text { Time Interval } \\
\text { (Total) }\end{array}$ & Max $(\mathbf{m m})$ & Min $(\mathbf{m m})$ & Mean $(\mathbf{m m})$ & Sx & Csx \\
\hline January & 134.87 & 21.84 & 78.59 & 31.72 & -0.09 \\
February & 227.08 & 13.21 & 87.73 & 50.43 & 1.13 \\
March & 432.56 & 15.75 & 114.84 & 89.20 & 3.03 \\
April & 226.06 & 46.23 & 110.40 & 49.42 & 0.89 \\
May & 257.81 & 38.86 & 97.16 & 53.87 & 1.85 \\
June & 226.57 & 38.35 & 109.06 & 54.03 & 0.83 \\
July & 243.08 & 24.89 & 103.59 & 62.99 & 1.07 \\
August & 276.86 & 17.53 & 97.37 & 62.00 & 1.54 \\
September & 202.69 & 39.88 & 93.22 & 50.85 & 0.91 \\
October & 261.37 & 20.32 & 118.65 & 58.91 & 0.59 \\
November & 236.98 & 24.13 & 100.52 & 50.32 & 1.20 \\
December & 177.04 & 60.45 & 117.83 & 34.73 & 0.08 \\
Spring & 562.61 & 159.26 & 322.40 & 100.40 & 0.60 \\
Summer & 454.66 & 105.16 & 310.01 & 96.42 & -0.24 \\
Fall & 520.45 & 169.16 & 312.39 & 92.16 & 0.65 \\
Winter & 437.13 & 188.47 & 284.32 & 66.60 & 0.55 \\
Annual & 1593.34 & 829.06 & 1228.96 & 217.36 & -0.26
\end{tabular}

\section{DATA AND METHODS}

The Mann Kendall test which is used for the trend analysis in this study is a nonparametric method. This is why a detailed definition of the data set is essential to evaluate and understand the outputs of the study. For this purpose, monthly, seasonally, and annually distribution of the precipitation data is drawn as Fig. 2, 3, 4,5 and 6 . It is also important to know the distribution for a better understanding of the hydrological situation of the study area.

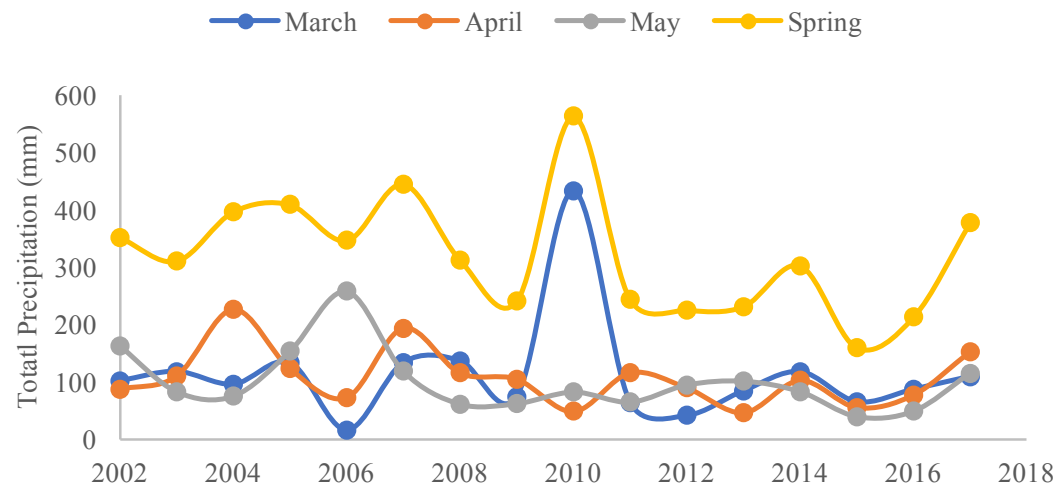

Fig. 2. Precipitation distribution during spring 
Fig. 2. shows that maximum and minimum records are belonging to march during the springtime. And, the maximum total precipitation is recorded in March 2010 as an extreme event.

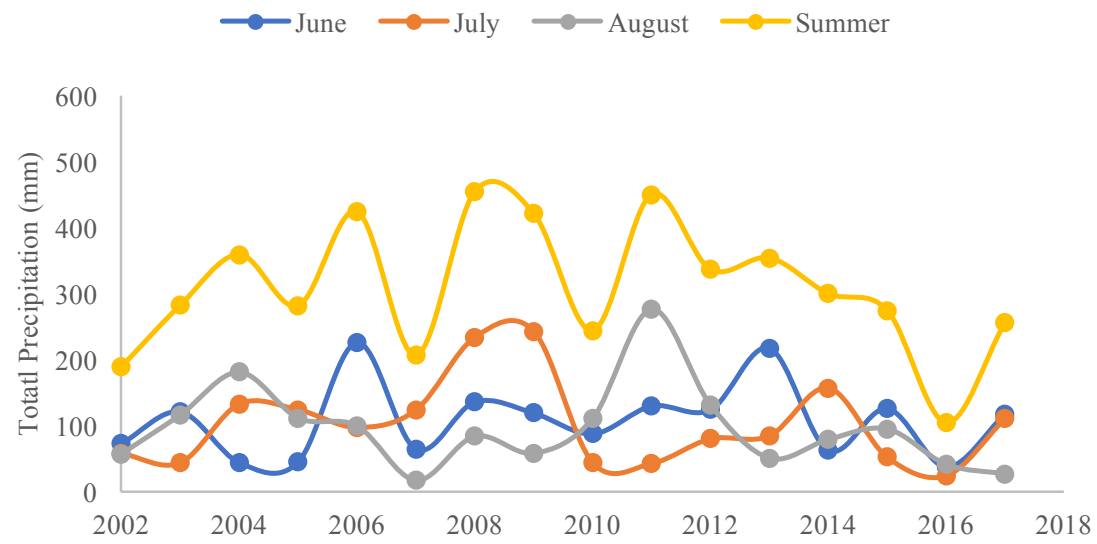

Fig. 3. Precipitation distribution during summer

Fig. 3. shows that maximum and minimum records are belonging to august during the summer season. And, the maximum total precipitation is recorded as $454.66 \mathrm{~mm}$ in 2008 as the sum of summertime.

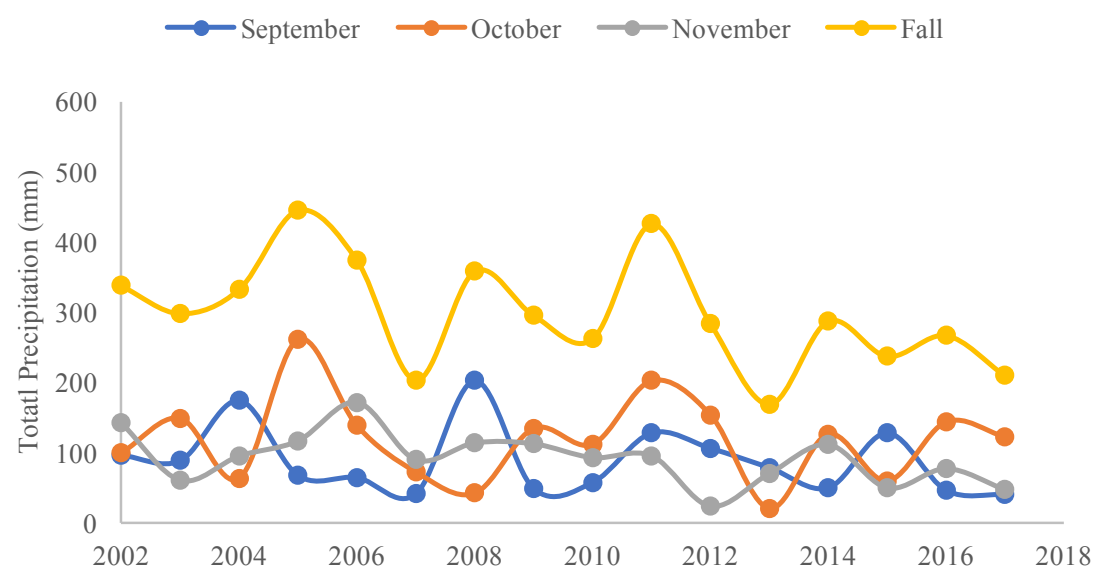

Fig. 4. Precipitation distribution during fall

Fig. 4. indicates that maximum and minimum records are belonging to October during the fall season. And, the maximum total precipitation is recorded as 445.52 $\mathrm{mm}$ in 2005 as the sum of the fall season. 


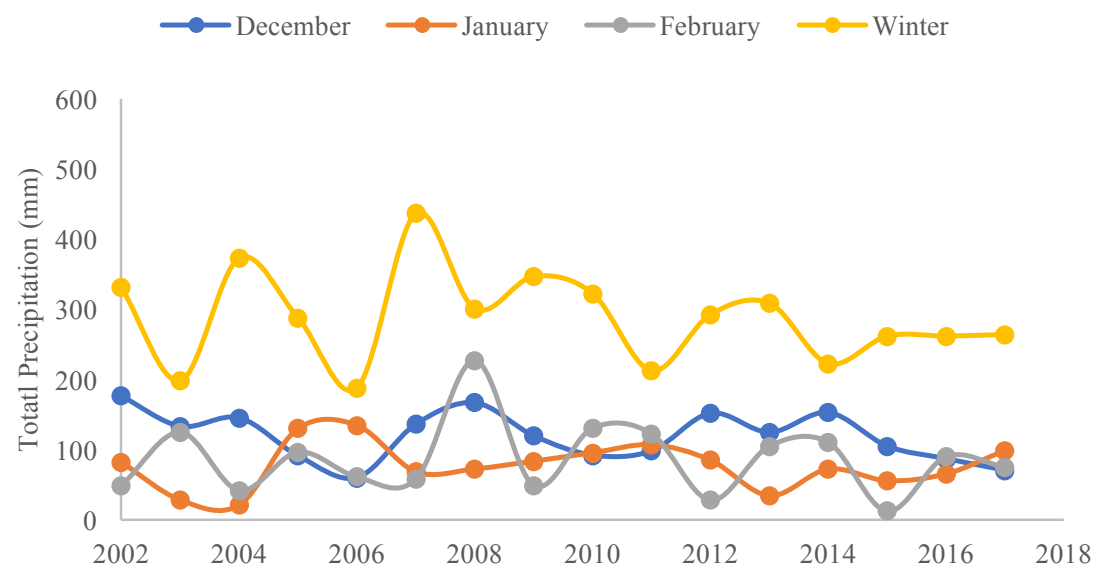

Fig. 5. Precipitation distribution during wintertime

Fig. 5. indicates that maximum and minimum records are belonging to February during the fall season. And, the maximum total precipitation is recorded as 437.13 $\mathrm{mm}$ in 2007 as the sum of the fall season.

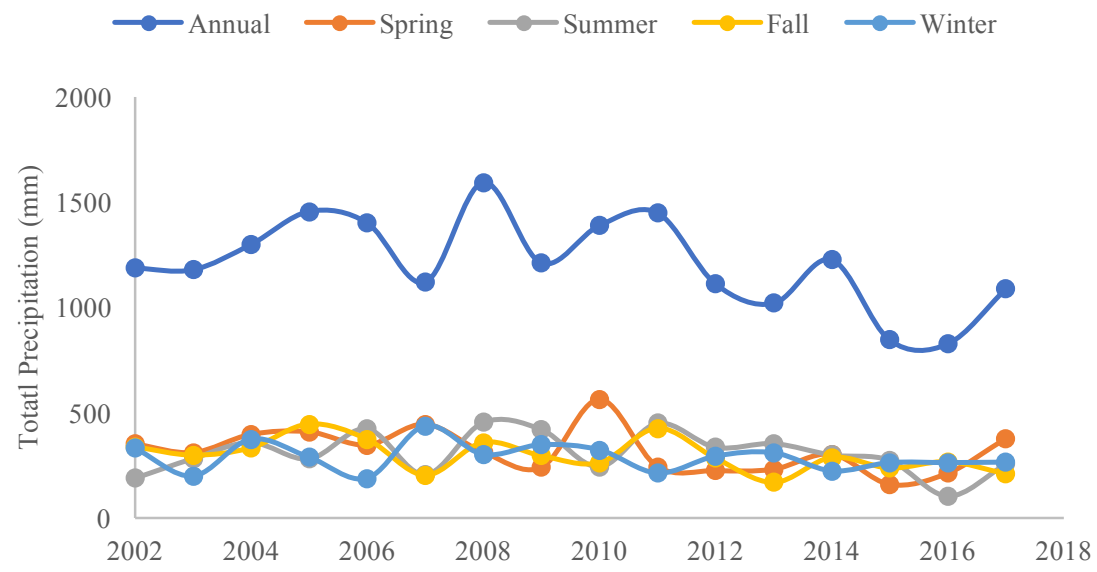

Fig. 6. Annual and Seasonal distribution of the sum of precipitation

The maximum annual total precipitation is $1593.34 \mathrm{~mm}$ belonging the 2008 year and the minimum is belonging to 2016 as $829.06 \mathrm{~mm}$.

\subsection{Mann Kendall Trend Analysis Method}

The Mann Kendall test is a non-parametric test that is used often for analyzing hydro climatologic data and for determining trend series. This method is a special application of Kendall's Tau test. Non-parametric tests are not related to the distribution of the data directly, it is more about the relationship between each time step numerical magnitude against one another (Mann, 1945; Kendall, 1975). The 
evaluation of the trend is based on the acceptance or rejection of the null hypothesis $\left(\mathrm{H}_{0}\right)$. Calculation of Mann Kendall test and evaluation is given as follows,

$$
S=\sum_{k=1}^{n-1} \sum_{j=k+1}^{n} \operatorname{sgn}\left(x_{j}-x_{k}\right)
$$

" $\mathrm{S}$ " is the Mann Kendall statistic and the calculation of " $\operatorname{sgn}\left(x_{j}-x_{k}\right)$ " is given with the formula (2).

$$
\operatorname{sgn}\left(x_{j}-x_{k}\right)=\left\{\begin{array}{rll}
+1 ; & \text { if } & \left(x_{j}-x_{k}\right)>0 \\
0 ; & \text { if } & \left(x_{j}-x_{k}\right)=0 \\
-1 ; & \text { if } & \left(x_{j}-x_{k}\right)<0
\end{array}\right.
$$

The mean of $\mathrm{E}[\mathrm{S}]=0$ and the variance $\sigma^{2}$ is,

$$
\begin{gathered}
\sigma^{2}=\frac{\left(n(n-1)(2 n+5)-\sum_{j=1}^{p} t_{j}\left(t_{j}-1\right)\left(2 t_{j}+5\right)\right)}{18} \\
z=\left\{\begin{array}{l}
\frac{S-1}{\sigma} \text { if } S>0 \\
0 \text { if } S=0 \\
\frac{S+1}{\sigma} \text { if } S<0
\end{array}\right.
\end{gathered}
$$

\subsection{Sen's Slope Method}

Calculation of a set of linear slopes is as follow,

$$
d_{k}=\frac{X_{j}-X_{i}}{j-i}
$$

at equation $5, n$ " is the number of the data, $\mathrm{i}$ and $\mathrm{j}$ are indices, $\mathrm{X}$ defines variable, $\mathrm{d}$ is slope for $1 \leq \mathrm{i} \leq \mathrm{j} \leq \mathrm{n}$.

And according to the median of all slopes, Sen's slope can be calculated. Where the $\mathrm{b}=$ median $\mathrm{d}_{\mathrm{k}}$, intercepts computation of each time step ,t” is given by equation 6 .

$$
a_{t}=X_{t}-b * t
$$

The median of all intercepts gives the corresponding intercept (Pohlert T., 2018).

\subsection{Spearman's Rho Test}

Spearman's Rho test is a similar test with the Mann Kendall test which allows users to identify non-parametric linear or non-linear trends. This method generally defines the situations that have no trend (Dahmen and Hall, 1990). The similarity of this method with the Mann Kendall method is based on the acceptation or rejection of the null hypothesis. If the $\mathrm{H}_{0}$ hypothesis is accepted for a time series then it means there is no trend. But if the $\mathrm{H}_{0}$ is rejected then it can be released there is an increasing or decreasing trend (Yue, et al., 2002). The test statistics (D) calculation step of this method is given with equations 7 and 8 .

$$
\begin{aligned}
& D=1-\frac{6 \sum_{i=1}^{n}\left(R_{i}-i\right)^{2}}{n\left(n^{2}-1\right)} \\
& Z_{S R}=D \sqrt{\frac{(n-2)}{\left(1-D^{2}\right)}}
\end{aligned}
$$

at equation $7, \mathrm{R}_{\mathrm{i}}$ ” is the $i$ th rank of observation and „n" is the length of the time series. If the calculated $Z_{S R}$ value is positive then the trend is being positive, the oppositely, if the $Z_{\mathrm{SR}}$ value is negative then the trend is being negative. 


\subsection{Linear Regression Analysis Method}

The linear regression trend investigation method is in use for the calculation of the single variable series trends. If the average trend line has a positive slope then there is an increasing trend, oppositely, if the slope of the regression line is negative then the trend is accepted as decreasing. The numerical size of the slope gives researchers an idea about the magnitude of the trend (Dabanlı, 2017).

\section{RESULTS AND DISCUSSIONS}

In this study, the precipitation trend of Middlesex County, USA is investigated using the Mann Kendall test, Spearman's rho test, linear regression trend analysis, and Sen's slope methods during 2002-2017 based on the one weather station records. Monthly, seasonally and annual evaluation is performed for the given time scale. Results of the Mann Kendall test and Sen's slope values are given in Table 2.

Table 2. Mann Kendall test results of each period

\begin{tabular}{c|ccccc|cc}
\multirow{2}{*}{ Time Step } & \multicolumn{6}{|c}{ Mann Kendall Results } & \multicolumn{2}{c}{ Sen's Slope } \\
\cline { 2 - 9 } & alpha & MK-stat & $\mathbf{z}$-stat & p-value & trend & alpha & slope \\
\hline January & 0.05 & 2 & 0.05 & 0.96 & no & 0.05 & 0.26 \\
February & 0.05 & -6 & -0.23 & 0.82 & no & 0.05 & -1.53 \\
March & 0.05 & -10 & -0.41 & 0.69 & no & 0.05 & -1.40 \\
April & 0.05 & -26 & -1.13 & 0.26 & no & 0.05 & -2.78 \\
May & 0.05 & -32 & -1.40 & 0.16 & no & 0.05 & -3.22 \\
June & 0.05 & 6 & 0.23 & 0.82 & no & 0.05 & 0.68 \\
July & 0.05 & -12 & -0.50 & 0.62 & no & 0.05 & -1.51 \\
August & 0.05 & -32 & -1.40 & 0.16 & no & 0.05 & -3.50 \\
September & 0.05 & -32 & -1.40 & 0.16 & no & 0.05 & -2.39 \\
October & 0.05 & -8 & -0.32 & 0.75 & no & 0.05 & -1.36 \\
November & $\mathbf{0 . 0 5}$ & $\mathbf{- 5 0}$ & $\mathbf{- 2 . 2 1}$ & $\mathbf{0 . 0 3}$ & yes & $\mathbf{0 . 0 5}$ & $\mathbf{- 4 . 4 1}$ \\
December & 0.05 & -30 & -1.31 & 0.19 & no & 0.05 & -3.02 \\
Spring & 0.05 & -44 & -1.94 & 0.05 & no & 0.05 & -10.43 \\
Summer & 0.05 & -14 & -0.59 & 0.56 & no & 0.05 & -1.99 \\
Fall & $\mathbf{0 . 0 5}$ & $\mathbf{- 5 0}$ & $\mathbf{- 2 . 2 1}$ & $\mathbf{0 . 0 3}$ & yes & $\mathbf{0 . 0 5}$ & $\mathbf{- 7 . 7 3}$ \\
Winter & 0.05 & -21 & -0.90 & 0.37 & no & 0.05 & -4.56 \\
Annual & 0.05 & -44 & -1.94 & 0.05 & no & 0.05 & -22.57 \\
& & & & & &
\end{tabular}

Aforementioned before, acceptance or rejection of the null hypothesis determines the trend according to the Mann Kendall approach. And Sen's slope method gives the magnitude of the trend. After the decision of the trend, negative values of the Mann Kendall test results indicate the direction of the trend as negative and the 
positive values of the Mann Kendall test show it as positive. The decision of acceptance of the $\mathrm{H}_{0}$ is made for the 95 confidence interval. According to the Mann Kendall trend test results presented in Table 2. only two trends are detected. " $\mathrm{z}$ "-stats are calculated as -2.21 for November and Fall time scales. Since mentioned z-stats are numerically lower than -1.96 (95\% confidence interval), trend directions of November and Fall are determined as negative. No more total precipitation trends are detected by using the Mann Kendall test.

The same evaluation for total precipitation is generated with Spearman's Rho test and results are shared with Table 3.

Table 3. Spearman's Rho test results of each period

\begin{tabular}{|c|c|c|c|c|c|}
\hline \multicolumn{6}{|c|}{ Spearman's Rho test results } \\
\hline Time Scale & $\alpha$ & $\begin{array}{l}\text { Critical } \\
Z \text { value }\end{array}$ & $\begin{array}{l}\text { Calculated } \mathrm{Z} \\
\text { value }\end{array}$ & Trend & Trend Direction \\
\hline January & & & -0.08 & No & - \\
\hline February & & & 0.00 & No & - \\
\hline March & & & 0.92 & No & - \\
\hline April & & & 1.14 & No & - \\
\hline May & & & 1.73 & No & - \\
\hline June & & & -0.28 & No & - \\
\hline July & & & 0.64 & No & - \\
\hline August & & & 1.37 & No & - \\
\hline September & 0.05 & 1.96 & 1.29 & No & - \\
\hline October & & & 0.25 & No & - \\
\hline November & & & 2.54 & Yes & Positive \\
\hline December & & & 1.34 & No & - \\
\hline Spring & & & 2.32 & Yes & Positive \\
\hline Summer & & & 0.51 & No & - \\
\hline Fall & & & 2.72 & Yes & Positive \\
\hline Winter & & & 0.99 & No & - \\
\hline Annual & & & 2.33 & Yes & Positive \\
\hline
\end{tabular}

Spearman's rho test was applied to the data set based on the $95 \%$ confidence interval (alpha=0.05). As the critical $Z$ value for 0.05 alpha is +-1.96 then the null hypothesis is accepted or rejected due to the comparison of calculated $Z_{\mathrm{SR}}$ and critical $\mathrm{Z}$ value. For monthly, seasonally, and annual evaluation of Spearman's Rho test, results are presented with Table 3. According to the results obtained, four positive trends are determined. $\mathrm{Z}_{\mathrm{SR}}$ values are calculated as 2.54, 2.32, 2.72, and 2.33 for November, Spring, Fall, Annual time scales respectively. According to the 
Spearman's Rho test results, It is seen that there is an increasing total precipitation trend in November, Spring, Fall, Annual during the 16 years period. No more trends were detected by using Spearman's Rho test for total precipitation.

The results of the regression trend investigation method are shared in Table 4.

Table 4. Linear Regression analysis trend test results of each period

\begin{tabular}{cc} 
Linear Regression Approach \\
\hline Time Scale & $\begin{array}{c}\text { Slope of the } \\
\text { regression line }\end{array}$ \\
\hline January & 0.00 \\
February & 0.00 \\
March & 0.00 \\
April & -0.03 \\
May & -0.04 \\
June & 0.01 \\
July & -0.01 \\
August & -0.01 \\
September & -0.03 \\
October & -0.01 \\
November & -0.07 \\
December & -0.05 \\
Spring & -0.02 \\
Summer & -0.01 \\
Fall & -0.03 \\
Winter & -0.02 \\
Annual & -0.01 \\
\hline &
\end{tabular}

According to the linear regression trend investigation approach, any positive trends were not detected. And, only one significant trend is detected as negative for the November time scale. This application is done additionally for having one more trend test on the evaluation of the results based on the comparison of the Mann Kendall test and Spearman's Rho test. As some of the results of the Mann Kendall test and Spearman's Rho test are in opposite directions, one more trend investigation application will be helpful to make a final conclusion.

\section{CONCLUSIONS}

Determination of the precipitation trend is an important issue for agriculturists, irrigation engineers, water planers, etc., to develop new strategies for the future. 
According to the statistical analyses based on the 95 percent confidence interval, it is concluded that there is a negative trend in November for monthly evaluation within the given period for the three of the methods used namely, Mann Kendall test, Sen's Slope test, and Linear Regression trend investigation approach. Oppositely, Spearman's Rho test gave a positive trend result for November. It should be known that each method has different calculation steps and methodologies and they may not validate one another. Hence, each result must be evaluated separately. But, for a final conclusion on a period, the sum of the results of each method can be used. For example, if we take consider the November results, we will see we have three negative trend results and one positive. So, It can be said that there is a negative total precipitation trend for November. For the Fall season, the Mann Kendall test gave a negative trend and the magnitude calculated with Sen's slope supported this finding. Additionally, even there is not found a significant trend with the linear regression trend approach, the trend direction is detected as negative. However, Spearman's rho test gave a positive trend result for the Fall season. Similarly, for the spring season and annual evaluation Spearman's rho test has positive trends. Any trends are not detected for the Summer season and other months in any methods used. This stationbased analysis is performed for Middlesex County, USA. For a more inclusive result, the authors suggest studying for more stations and for a larger time scale.

\section{ACKNOWLEDGEMENTS}

The authors would like to thank United States Geological Survey (USGS) for their effort on measurements and for sharing data set.

\section{REFERENCES}

1. Bacanlı, Ü. G., \& Tanrikulu, A. (2017). Trends Analysis of Evaporation Datas in Aegean Region. Afyon Kocatepe Üniversitesi Fen ve Mühendislik Bilimleri Dergisi, 17, 980-987.

2. Dabanlı, İ., (2017). Türkiye'de İklim Değişikliğinin Yağış-Sıcaklığa Etkisi ve Kuraklık Analizi: Akarçay Örneği. İstanbul Tek. Üniversitesi Fen Bilim. Enstitüsü.

3. Dahmen E. R. \& Hall M. J. (1990) Screening of hydrological data: tests for stationarity and relative consistency. ILRI, The Netherlands, p 58, Publication \#49

4. Demirci, M., \& Kaya, Y. Z. (2019). Estimation of Keban Dam Reservoir Level in Turkey Using Artificial Neural Network and Support Vector Machines. 11th Air and Water Componenets Conference, 197-205. https://doi.org/10.24193/AWC2019_20

5. Demirci, M., Taşar, B., \& Kaya, Y. Z. (2018). Estimation of Groundwater Level Fluctuations Using Neuro-Fuzzy and Support Vector Regression Models. International Journal of Advanced Engineering Research and Science (IJAERS), 5(12), 206-211. https://doi.org/10.22161/ijaers.5.12.29

6. Ercan, B., \& Yüce, M. İ. (2018). Kilis ili aylık sıcaklık ve yağış verileri trend analizi. DÜMF Mühendislik Dergisi, 9(2), 947-953.

7. Fathian, F., Morid, S. \& Kahya, E. (2015). Identification of trends in hydrological and climatic variables in Urmia Lake basin, Iran. Theor Appl Climatol 119, 443$464 \mathrm{https}: / /$ doi.org/10.1007/s00704-014-1120-4 
8. Fukushima, A., Kanamori, H., \& Matsumoto, J. (2019). Regionality of long-term trends and interannual variation of seasonal precipitation over India. Progress in Earth and Planetary Science, 6(1). https://doi.org/10.1186/s40645-019-0255-4

9. Kahya, E., Kalayc1, S., (2004). Trend analysis of streamflow in Turkey,Journal of Hydrology,Volume 289, Issues 1-4,Pages 128-144,ISSN 00221694,https://doi.org/10.1016/j.jhydrol.2003.11.006.

10. Kendall, M.G. (1975). Rank Correlation Methods, Charless Griffin, London.

11. Kisi, O. (2008). The potential of different ANN techniques in evapotranspiration modelling. Hydrological Processes, 22(14), 2449-2460. https://doi.org/10.1002/hyp.6837

12. Kisi, O. (2015). Pan evaporation modeling using least square support vector machine, multivariate adaptive regression splines and M5 model tree. Journal of Hydrology, 528, 312-320. https://doi.org/10.1016/j.jhydrol.2015.06.052

13. Mahmood, R., Jia, S., \& Zhu, W. (2019). Analysis of climate variability, trends, and prediction in the most active parts of the Lake Chad basin, Africa. Scientific Reports, 9(1), 1-18. https://doi.org/10.1038/s41598-019-42811-9

14. Mamak, M., Üneş, F., Kaya, Y. Z., \& Demirci, M. (2017). Evapotranspiration Prediction Using Adaptive Neuro-Fuzzy Inference System and Penman FAO 56 Equation for St. Johns, FL, USA. Proccedings of 10th International Conference "Environmental Engineering," (April), 27-28. https://doi.org/10.3846/enviro.2017.085

15. Mann, H, B. (1945). Nonparametric tests against trend. Econometrica, 13, 245-259.

16. Partal, T. and Kahya, E. (2006), Trend analysis in Turkish precipitation data. Hydrol. Process., 20: 2011-2026. https://doi.org/10.1002/hyp.5993

17. Serencam, U. (2019). Innovative trend analysis of total annual rainfall and temperature variability case study: Yesilirmak region, Turkey. Arabian Journal of Geosciences, 12(23). https://doi.org/10.1007/s12517-019-4903-1

18. Shiri, J., Kişi, Ö., Landeras, G., López, J. J., Nazemi, A. H., \& Stuyt, L. C. P. M. (2012). Daily reference evapotranspiration modeling by using genetic programming approach in the Basque Country (Northern Spain). Journal of Hydrology, 414-415, 302-316. https://doi.org/10.1016/j.jhydrol.2011.11.004

19. Tosunoğlu, F. (2017). Trend Analysis of Daily Maximum Rainfall Series in Çoruh Basin. Iğdır Üni. Fen Bilimleri Enst. Der, 7(1), 195-205.

20. Thorsten, P. (2018). Non-Parametric trend tests and change-point detection. This work is licensed under a Creative Commons License

21. Üneş, F., Demirci, M., İspir, E., Kaya, Y. Z., Mamak, M., Taşar, B., Estimation of Groundwater Level Using Artificial Neural Networks: a Case Study of Hatay-Turkey. „Environmental Engineering” 10th International Conference Vilnius Gediminas Technical University. https://doi.org/10.3846/enviro.2017.092

22. Üneş, F., Bahadırlı, Z. M., Demirci, M., Tasar, B., Varçin, H., \& Kaya, Y. Z. (2018a). Determination of Groundwater Level Fluctuations by Artificial Neural Networks. Natural and Engineering Sciences, 3(November), 35-42.

23. Üneş, F., Demirci, M., Taşar, B., Kaya, Y. Z., \& Varçin, H. (2019). Modeling of Dam Reservoir Volume Using Generalized Regression Neural Network, Support Vector Machines And M5 Decision Tree Models. Applied Ecology and Environmental Research, 17(3), 1-21. https://doi.org/10.15666/aeer/1703_70437055

24. Üneş, F., Doğan, S., Tasar, B., Kaya, Y. Z., \& Demirci, M. (2018b). The Evaluation and Comparison of Daily Reference Evapotranspiration with ANN and Empirical Methods. Natural and Engineering Sciences, 3(November), 54-64. 
25. Yue, S., P. Pilon, G. Cavadias (2002). Power of the Mann-Kendall and Spearman's rho tests for detecting monotonic trends in hydrological series. J. Hydrol., 259 (2002), pp. 254-271

26. Zhao, L., Xia, J., Xu, C. yu, Wang, Z., Sobkowiak, L., \& Long, C. (2013). Evapotranspiration estimation methods in hydrological models. Journal of Geographical Sciences, 23(2), 359-369. https://doi.org/10.1007/s11442-013-1015-9 